\title{
AVALIAÇÃO DAS CARACTERÍSTICAS AMBIENTAIS DE OCORRÊNCIAS DAS FEIÇÕES EROSIVAS LINEARES NOS LIMITES DEPRESSÃO-CUESTA - ANALÂNDIA (SP)
}

\author{
Estêvão Botura Stefanuto \\ Universidade Estadual Paulista - UNESP/Rio Claro \\ Mestrando do Programa de Pós-Graduação em Geografia \\ esteva01508@hotmail.com \\ Cenira Maria Lupinacci \\ Universidade Estadual Paulista - UNESP/Rio Claro \\ Docente do Programa de Pós-Graduação em Geografia \\ cenira@rc.unesp.br
}

\begin{abstract}
RESUMO
As áreas de contato entre as depressões de borda de bacias sedimentares e os relevos cuestiformes, quando combinadas a intenso uso agrícola, podem sofrer processos erosivos lineares. Portanto, objetiva-se discutir a evolução de feições erosivas lineares, a partir de suas interações com a litologia, os solos, a declividade e o uso da terra em setor de transição depressão-cuesta localizado em Analândia (SP). Buscando atingir o objetivo, utilizou-se um conjunto de técnicas cartográficas a fim de mapear cada uma das variáveis consideradas. Através da metodologia utilizada, constatou-se uma expressiva associação das feições erosivas à litologias arenosas e a solos espessos e pouco espessos. Os sulcos e ravinas apresentaram incidência considerável na classe de declividade de 5 a 12\%, a qual, teoricamente, é avaliada como adequada a diversos tipos de uso da terra. Ainda em relação ao uso da terra, as feições erosivas lineares correlacionaram-se às áreas de pasto limpo e vegetação arbórea, fato teoricamente inesperado. Dessa forma, é possível afirmar que as características geomorfológicas do contato cuesta-depressão, junto a um intenso uso da terra, podem estar dinamizando os processos erosivos lineares em diversificadas condições físicas, algumas destas consideradas de baixa potencialidade para o desenvolvimento desses processos.
\end{abstract}

Palavras-chave: Erosão. Morfometria. Litologia. Solos. Uso da terra.

\section{EVALUATION OF ENVIRONMENTAL CHARACTERISTICS OF LINEAR EROSIVE FEELINGS OCCURRENCES IN THE LIMITS OF DEPRESSION- CUESTA - ANALÂNDIA (SP)}

\begin{abstract}
The contact between the sedimentary shed edge depressions and the cuestiform reliefs when combined with intense agricultural use may start linear erosive processes. As far as it is concerned, this article aims to discuss the evolution of linear erosive features, from their interactions with lithology, soils, declivity and land use in a depression-cuesta transition located in Analândia (SP). Committed to achieving its goals, a set of cartographic techniques were used in order to map each of the considered variables. Through the methodology used an expressive association of the erosive features with the sandy lithologies and with the thick soils and the little thick soils was verified. The rill erosion and ravines presented a considerable incidence on the slopes gradient from 5 to $12 \%$, which, theoretically, is evaluated as suitable for various types of land use. On that same ground, linear erosive features correlated to areas of clean pasture, but also to arboreal vegetation, a fact theoretically unexpected. In this way, it is possible to claim that the geomorphological characteristics of the cuesta-depression contact, together with an intense use of the earth, can be dynamizing the linear erosive processes over diverse physical conditions, some of these considered of low potential for the development of these processes.
\end{abstract}

Keywords: Erosion. Morphometry. Lithology. Soils. Land use.

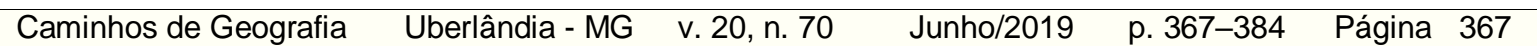




\section{INTRODUÇÃO}

Durante o Neo-Ordoviciano (460 Milhões de anos) inicia-se, a partir da supersequência do Rio Ivaí, a formação da Bacia Sedimentar do Paraná (MILANI et al. 2007), a qual caracteriza-se como uma grande estrutura do território nacional (ROSS, 2009), destacando-se como uma das maiores bacias sedimentares do mundo e segunda maior do Brasil com 1,5 milhão de quilômetros quadrados e 7 mil metros de espessura (MILANI et al. 2007).

Junto ao setor leste da Bacia Sedimentar do Paraná se desenvolve uma depressão periférica que se constitui em relevo típico do contato dessas estruturas com maciços antigos, reconhecido por autores clássicos como Derruaux (1965). Na Bacia Sedimentar do Paraná a depressão periférica se estende continuamente da região norte do Estado de São Paulo até o nordeste do Rio Grande do Sul. Junto à depressão circundante desenvolvem-se escarpas que se identificam como frentes de cuestas, que, no caso da borda leste, são formadas por rochas efusivas (ROSS, 2009).

Com isso, no estado de São Paulo, o relevo de cuesta se estende dos municípios de Franca a Chavantes, ocupando extensa área, intensamente utilizada para fins agrícolas. Almeida (1949; 1974) caracteriza esse setor como um relevo acidentado, atravessado pelos principais rios consequentes deste complexo (Tietê, Paranapanema, Grande, Pardo e Mogí-Guaçú). Os rios são responsáveis pela abertura das percées e pela esculturação do relevo, que em São Paulo apresenta, segundo diversos autores (PENTEADO, 1974; CASSETI, 2001 e GUERRA e GUERRA, 2010), a ocorrência de estruturas monoclinais e a alternância de resistência das camadas, que se constituem em elementos indissociáveis da formação das cuestas e da depressão periférica.

Assim, os contatos estruturais entre as camadas litológicas de maior resistência e as mais friáveis, se definem a partir dos derrames basálticos datados do Mesozoico. Praticamente em todos os setores da Bacia Sedimentar do Paraná são identificados tais derrames, que se constituem em camadas de grande resistência à evolução do relevo, uma vez que após $100 \mathrm{Ma}$ de retrabalhamento erosivo, ainda restam três quartos da área total da bacia recoberta por rochas da Formação Serra Geral (MILANI et al. 2007).

Numa escala de análise local do relevo paulista, Christofoletti e Queiroz Neto (1961) identificaram na Serra de Santana a ocorrência de derrames basálticos, subdivididos em três conjuntos: o superior, responsável por capear os espigões; o intermediário, indicado como sustento das escarpas; e o inferior, onde há a origem da soleira estrutural na qual se desenvolve grande parte do planalto de Campo Alegre.

Alguns setores de contato entre litologias de resistências variadas apresentam ainda intensa ocorrência de falhamentos. Tal fato foi constatado por Stefanuto e Lupinacci (2016) em estudo aplicado à porção central do relevo cuestiforme paulista. Neste setor, a partir de uma escala de médio detalhe, foram mapeados lineamentos de até 1500 metros de extensão (STEFANUTO E LUPINACCI, 2016), os quais apresentaram uma relação intrínseca com o desenvolvimento de feições erosivas do tipo voçoroca (STEFANUTO E LUPINACCI, 2017a).

Sobre o relevo do estado de São Paulo se registra ainda intenso uso da terra, tanto agrícola como urbano. A afirmação evidencia-se quando se analisam os dados levantados pelo Instituto de Economia Agrícola (IEA) para o ano de 2017 e verifica-se que apenas 12,4\% do território paulista é recoberto por mata. No que concerne ao uso da terra paulista, destaca-se a pesquisa de Produção Agrícola Municipal (PAM), desenvolvida pelo IBGE no ano de 2016, na qual se identifica que a microrregião de Franca (SP), localizada ao norte da unidade geomorfológica mencionada, apresentava, em 2016, área expressiva de produção agrícola, com destaque para a cana-de-açúcar, $21,7 \%$ de área de ocupação; e o café (13,7\%). Mais ao centro da depressão periférica, de acordo com Stefanuto e Lupinacci (2017b) em estudo aplicado a setores da Serra do Cuscuzeiro, localizada em Analândia (SP), no ano de 2010, 73,2\% da área central analisada era ocupada por pastagens classificadas como pastos limpos, que caracterizam gramíneas para fins agropecuários. Por fim, no compartimento sul da depressão periférica, especificamente na bacia do Rio Capivara localizada em Botucatu (SP), Campos et al. (2015) identificaram novamente uma predominância das áreas de pastagem, representada pela ocupação de $31,6 \%$ da área analisada. 
Assim, compreendendo o contato Depressão Periférica Paulista-Cuesta como uma área de fragilidade estrutural, marcada pela ocorrência de estruturas monoclinais e a alternância de resistência das camadas, e sendo a mesma submetida a um expressivo uso agrícola, firma-se a necessidade de compreensão desta interação, a fim de analisar o desenvolvimento de feições erosivas lineares e a consequente degradação dos solos. Com relação à influência tectônica sobre tais feições, Stefanuto e Lupinacci (2016), estudando a região em escala de médio detalhe, já avaliaram que o lineamento estrutural mantém relação intrínseca com o desenvolvimento de feições erosivas do tipo voçoroca.

Portanto, a fim de colaborar com os estudos que visam compreender os mecanismos de desenvolvimento de feições erosivas lineares, mediante a atuação de agentes antropomórficos, tem-se como objetivo neste artigo analisar a evolução destas feições localizadas no setor cuestiforme de Analândia (SP) (Figura 1), utilizando um conjunto de técnicas geomorfológicas que colaboram para um melhor entendimento dos processos erosivos em ambientes rurais.

Figura 1 - Localização da bacia hidrográfica estudada no Brasil, no estado de São Paulo e no município de Analândia.

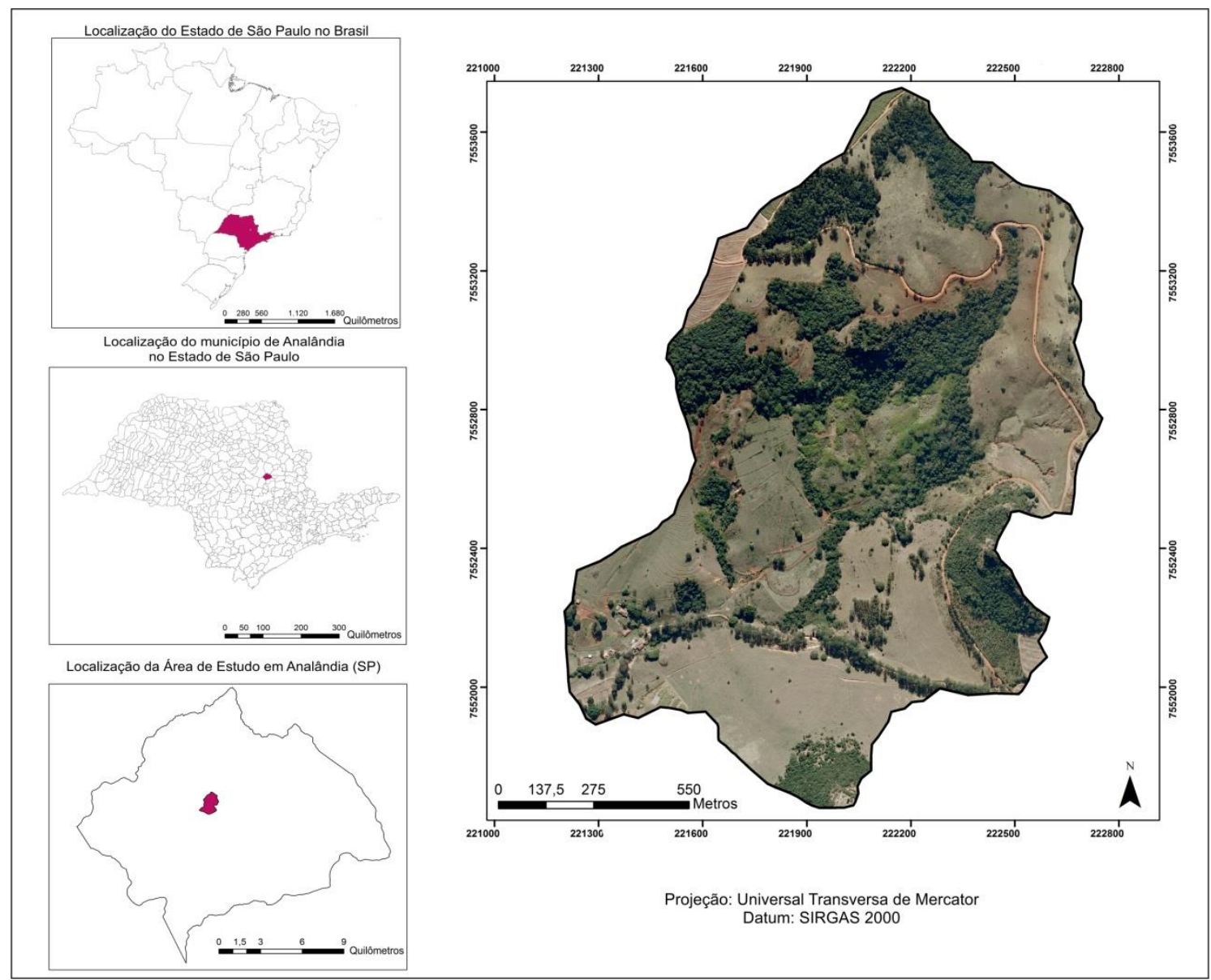

Fonte - IBGE, 2017; EMPLASA, 2010.

Destaca-se ainda que a área analisada está situada na porção central da Serra do Cuscuzeiro (CHRISTOFOLETTI E QUEIROZ NETO, 1961), constituindo-se na alta bacia do Córrego Santa Terezinha. Essa área, segundo levantamento do Instituto Geológico de São Paulo de 1984, apresenta significativa variação geológica, representada pelo contato entre cinco formações diversas (Pirambóia, Botucatu, Serra Geral, Itaqueri e Santa Rita do Passa Quatro). Ainda, Stefanuto e Lupinacci (2016), caracterizam o relevo da região como complexo por apresentar morros testemunhos e esporões e setores com topografia acidentada, os quais refletem a significativa influência tectônica devidamente discutida pelos autores. Além disso, segundo Pinton (2011), essa área constitui-se em um setor de franca expansão agrícola, com a consolidação, a partir de 1988, de áreas de pastagem e cana-de-açúcar em maior relevância. 
Tais elementos constituíram-se em dados estratégicos para que o objetivo proposto fosse alcançado.

\section{METODOLOGIA}

Buscando atingir o objetivo proposto, apresentam-se a seguir os procedimentos técnicos empregados para a elaboração dos produtos cartográficos. Os mapeamentos foram elaborados com o auxílio do software ArcGis 10.1.

\section{Base cartográfica e fotointerpretação}

A base cartográfica foi obtida junto ao Instituto Geográfico Cartográfico do Estado de São Paulo (IGC), elaborada em 1979, em escala de 1:10.000. As folhas utilizadas para esta pesquisa foram: Serra da Estrela (SF-23-Y-A-I-2-NO-E) e Analândia I (SF-23-Y-A-I-2-NO-F), sendo as mesmas vetorizadas através da ferramenta arcscan, presente no Arcgis 10.1.

Já as fotografias aéreas utilizadas foram adquiridas junto a três diferentes instituições, sendo as de 1962, na escala aproximada de 1:25.000, adquiridas junto ao Instituto Agronômico de Campinas; as de 1988, na escala aproximada de 1:40.000, obtidas junto ao acervo de fotografias aéreas do DEPLAN/IGCE; e as de 2010, na escala aproximada de 1:25.000, obtidas via requerimento enviado a Empresa Paulista de Planejamento Metropolitano (EMPLASA). Destaca-se que os mapeamentos realizados encontram-se compatíveis com a escala de 1:10.000. Para isso foi efetuada aproximação por meio do recurso de zoom existente no ArcGis. Informa-se ainda que esse procedimento de aproximação obedeceu aos recursos disponíveis na resolução das fotografias, buscando evitar distorções relevantes nos pixels da imagem de menor detalhe (1:40.000). Ainda, buscando auxiliar no processo de fotointerpretação, as fotografias aéreas de 1962 e 1988 foram submetidas à técnica do anáglifo, descrita por Souza e Oliveira (2012). Para tal, utilizou-se o programa de uso gratuito StereoPhoto Maker 4.34. As fotografias ortorretificadas de 2010 não foram submetidas a tal técnica, uma vez que não permitiram esteroscopia.

\section{Carta de Uso e Ocupação da Terra}

O referido mapeamento foi formulado a partir das ortofotos do ano de 2010. Para tal, utilizou-se a proposta de fotointerpretação de Ceron e Diniz (1966), visto que os autores apresentam algumas chaves que facilitam a identificação de determinadas culturas e a compreensão de algumas variáveis típicas do uso da terra do interior do estado de São Paulo.

No ambiente do software ArcGis 10.1, criaram-se layers no formato polígono referentes às classes de uso da terra identificadas na área desta pesquisa. As mesmas foram delimitadas através das ferramentas Straight Segment e Trace. Destaca-se que as classes e as cores propostas pelo IBGE (2013) não contemplaram todos os elementos de uso identificados nesta pesquisa, assim foi criado um novo grupo de classes e cores visando suprir as demandas.

Das treze classes de uso da terra mapeadas, cinco seguiram à proposta de classificação do IBGE (2013), sendo as mesmas: corpo d'água continental, área descoberta, silvicultura, pastagem e vegetação florestal. Destaca-se que as duas últimas necessitaram de ajustes, sendo a classe pastagem correlacionada aos pastos limpos, ou seja, pastos tratados mecanicamente; e a classe vegetação florestal representada pela vegetação arbórea, como Savana Florestal (Cerradão) de acordo com o IBGE (2013).

Já oito classes foram criadas visando maior detalhamento do mapeamento (área construída, estrada rural, pasto sujo, pasto degradado, solo exposto, vegetação de área úmida, vegetação invasora e cana-de-açúcar). À classe área construída incorporou-se setores de construção civil dissociados da malha urbana, como sedes de propriedades rurais; à estrada rural, vias de acesso sem pavimentação; à classe pasto sujo, setores destinados ao uso da pecuária extensiva; ao pasto degradado, áreas intensamente atingidas por feições erosivas; ao solo exposto, setores sem cobertura vegetal; à vegetação de área úmida, setores ocupados por vegetação hidrófila; à vegetação invasora, áreas com a presença da espécie Tecoma stans, classificada por Pedrosa-Macedo e Bredow (2004) como espécie invasora, e à cana-de-açúcar, setores agrícolas com o plantio e manejo típico dessa cultura. 
Com os polígonos de uso delimitados, buscou-se ainda quantificar os dados de uso da terra, visando uma melhor compreensão da dimensão ocupada por cada classe no setor. Para tal, utilizou-se a ferramenta de quantificação Calculete Geometry.

Buscando exemplificar as classes de uso da terra descritas, apresentam-se, na Figura 2, com as características de cada uso na área de estudo.

Figura 2 - Características das classes de uso e ocupação da terra.

\begin{tabular}{|c|c|c|c|}
\hline Área Construída & Pasto Limpo & Pasto Sujo & \\
\hline Área Descoberta & Silvicultura & \\
\hline Cana-de-Açúcar & Solo Exposto & \\
\hline $\begin{array}{c}\text { Corpo D'Água } \\
\text { Continental }\end{array}$ & Vegetação Arbórea & \\
\hline Estrada Rural & & & \\
\hline Vasto Degradado & & Vegetação de área úmida & \\
\hline
\end{tabular}

Fonte - EMPLASA, 2010.

\section{Carta de Declividade}

Inicialmente foram definidas as classes de declividade buscando manter a proximidade dos valores sugeridos por De Biasi (1992) (Quadro 1). As classes de baixa declividade foram demarcadas por cores claras, escurecendo o tom com o aumento da declividade, como De Biasi $(1970,1992)$ recomenda.

Destaca-se que após a formulação do primeiro modelo da carta de declividade, elaborada por meio da ferramenta slope, no software ArcGis, identificaram-se erros de processamento nos setores de fundos de vale e topos representados no produto cartográfico. Ambos foram classificados como setores planos, não havendo correlação com os dados obtidos em campo e apresentados por Stefanuto e Lupinacci (2016), que caracterizam o setor com alta declividade e topos convexos. Em campo, foi possível constatar que os vales nem sempre são simétricos, como mapeado inicialmente pelo procedimento automático. Além disso, a localização do setor em um ambiente quente e úmido, no qual a ação denudativa da água é intensa, gera uma tendência a convexização dos topos.

Assim, visando minimizar os erros nos referidos setores, adicionaram-se linhas de quebra com os valores médios de elevação nos fundos de vale e topos. Os valores médios corresponderam à metade da equidistância; por exemplo, trechos do fundo de vale envoltos por curva de nível com valor de 670 metros, receberam uma linha de quebra com valor de elevação de 667,5 metros, considerando que o rio encontra-se em altitude inferior à da curva que envolve o vale, contudo não atinge ainda a altitude da próxima curva de nível (665); nos topos, calculou-se um 
acréscimo ao valor da última curva de nível registrada pela base topográfica na ordem da metade do valor da equidistância das curvas.

Quadro 1 - Definição das classes de declividade.

\begin{tabular}{|c|c|}
\hline Classes de declividade (\%) & Critérios \\
\hline$\leq 2 \%$ & $\begin{array}{l}\text { Constituem-se em áreas alagáveis, nas quais há } \\
\text { principalmente perda de materiais em solução pela } \\
\text { ação da infiltração e percolação das águas. }\end{array}$ \\
\hline $2+5 \%$ & $\begin{array}{l}\text { São áreas suscetíveis a alagamentos, nas quais o } \\
\text { uso agrícola pode ser intenso pela facilidade de } \\
\text { mecanização. (PINTON e CUNHA, 2015). }\end{array}$ \\
\hline $5-12 \%$ & $\begin{array}{l}\text { 12\% é o limite máximo do emprego de mecanização } \\
\text { na agricultura (DE BIASI, 1992). }\end{array}$ \\
\hline $12 \vdash 30 \%$ & $\begin{array}{l}\text { São áreas com intensa ocorrência de feições } \\
\text { erosivas lineares e que congregam a correlação } \\
\text { entre média e alta declividade e usos da terra com } \\
\text { baixo emprego de técnicas agrícolas. O limite de } \\
30 \% \text { também se justifica em função da Lei Lehman } \\
\text { (Lei no } 6.766 \text { ) que prevê restriçóes ao uso urbano a } \\
\text { partir desse declive. }\end{array}$ \\
\hline $\begin{array}{l}30+45 \% \\
>45 \%\end{array}$ & $\begin{array}{l}\text { De acordo com o Capítulo III Artigo } 11 \text { da Lei } \mathrm{n} \text { - } \\
12.651 \text {, os setores com declives entre } 45 \% \text { a } 100 \% \\
\text { são áreas de uso restrito. Nesses "são permitidos o } \\
\text { manejo florestal sustentável e o exercício de } \\
\text { atividades agrossilvipastoris, bem como a } \\
\text { manutenção da infraestrutura física associada ao } \\
\text { desenvolvimento das atividades, observadas boas } \\
\text { práticas agronômicas, sendo vetada a conversão de } \\
\text { novas áreas, excetuadas as hipóteses de utilidade } \\
\text { pública e interesse social". Para Mathias (2016) são } \\
\text { ainda áreas críticas do ponto de vista da dinâmica } \\
\text { erosiva as quais podem representar as rupturas } \\
\text { relacionadas a taludes erosivos das voçorocas. }\end{array}$ \\
\hline
\end{tabular}

Fonte - Os autores.

\section{Carta de Feições Lineares Erosivas}

A identificação das feições erosivas partiu do princípio que essas são expressas nas fotografias aéreas a partir de mudanças de tonalidades e texturas (Figura 3). Utilizou-se também das descrições e simbologias de Tricart (1965) e Verstappen e Zuidan (1975) para formulação de mapas geomorfológicos, as quais auxiliaram na fotointerpretação. Empregaram-se ainda as definições apresentadas por uma compilação de bibliografias (FURLANI, 1980; GOUDIE, 2004; AUGUSTIN E ARANHA, 2006; SOIL SCIENCE SOCIETY OF AMERICA, 2008) que embasaram a identificação e classificação das formas erosivas em sulcos, ravinas e voçorocas. Assim, os sulcos erosivos, foram entendidos como feições lineares rasas, passíveis de serem obliteradas por maquinário agrícola, que se apresentaram como linhas de coloração esbranquiçada; já as ravinas, foram compreendidas como feições mais profundas que os sulcos, impossíveis de serem obliteradas por técnicas conservacionistas tradicionais; além da cor esbranquiçada ou escura, apresentaram textura granulada e dimensão superior à dos sulcos. As voçorocas destacaram-se nas fotografias aéreas pela presença de taludes erosivos íngremes e vales mais alargados. Convém esclarecer que tais princípios foram estabelecidos a partir de reconhecimento de campo.

Para a vetorização das feições erosivas, atribuíram-se layers do tipo linha aos sulcos e ravinas, por não evidenciarem áreas extensas no setor estudado; e layers do tipo polígono para as erosões classificadas como voçorocas, por ocuparem áreas maiores. Após as feições erosivas serem identificadas nos três cenários de análise, atribui-se um buffer as erosões delimitadas como linha, uma vez que o objetivo era quantificar a extensão da área de ocorrência de cada fenômeno erosivo. Assim, adicionou-se um buffer de $10 \mathrm{~cm}$ aos sulcos erosivos e um buffer de $50 \mathrm{~cm}$ as ravinas. Essas medidas se devem as características das formas erosivas constatadas pela análise das fotografias aéreas. 
Figura 3 - Características das feições erosivas lineares.

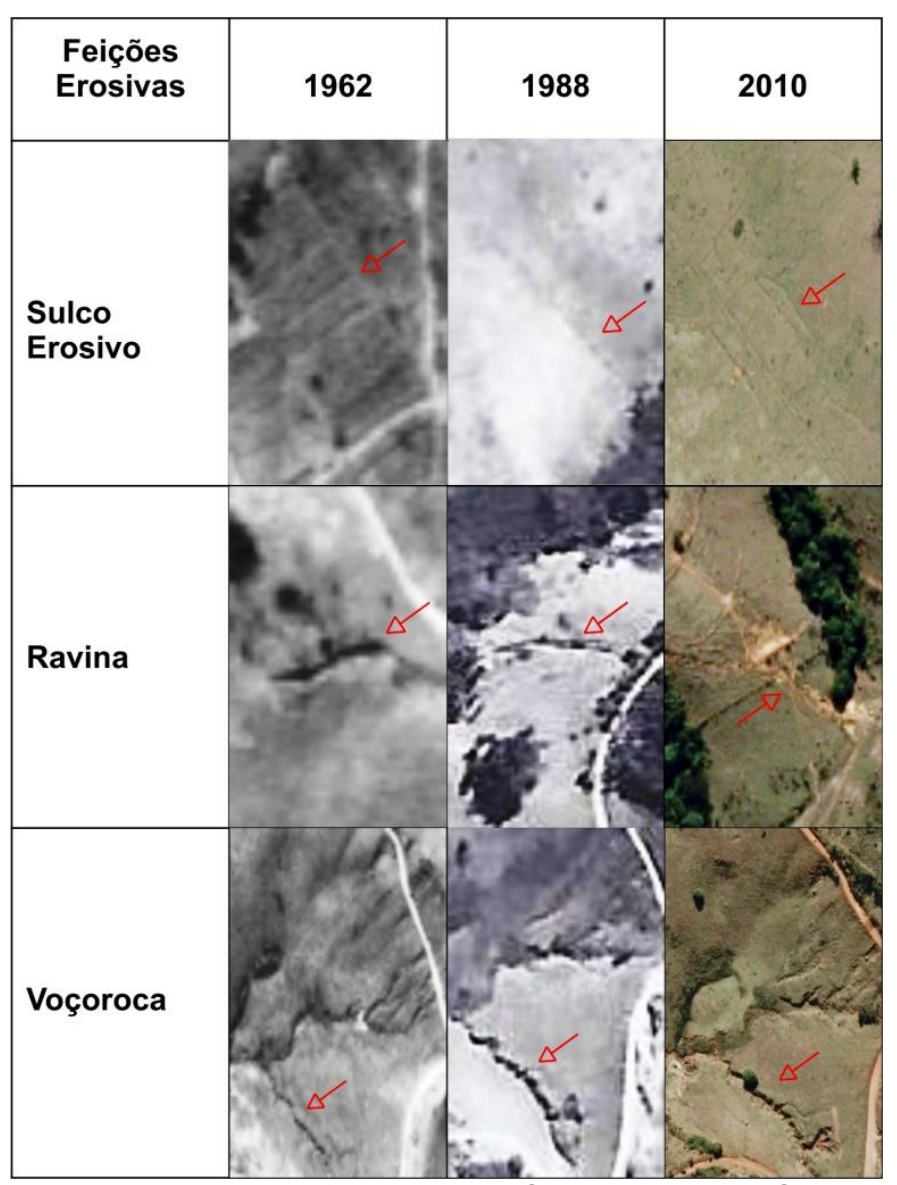

Fonte - Terrafoto, 1962; BASE, 1988; EMPLASA, 2010.

Posteriormente, visando reconhecer as características pedológicas, geológicas, morfométricas e de uso da terra sobre as quais ocorrem as feições erosivas, foram sobrepostos os polígonos de cada feição erosiva aos referidos dados. Por estarem no formato polígono, os dados pedológicos, geológicos e de uso da terra foram submetidos às ferramentas clip e os valores de área de cada feição em relação aos mesmos foram obtidos através da ferramenta Caculate Geometry. Já o dado morfométrico, representado pela declividade, foi gerado no formato raster sendo necessário procedimento específico.

Com a carta de declividade formulada, foi necessário um procedimento que permitisse quantificar a área de ocorrência de cada classe de declividade em relação às feições erosivas lineares. Assim, através da ferramenta raster dataset $\rightarrow$ copy raster, foi possível ativar a tabela de atributos do produto, possibilitando o uso da ferramenta field calculator, a qual, através da multiplicação da coluna com os valores de declividade por 1 (área do pixel utilizado), permitiu calcular o valor de área de cada classe de declividade em $\mathrm{km}^{2}$ e posterior recorte da informação pelos polígonos das feições erosivas lineares.

\section{RESULTADOS E DISCUSSÃO}

Apresenta-se a seguir uma análise da ocorrência das feições erosivas lineares identificadas na área de estudo em cada classe de solo, litologia, declividade e uso da terra. A localização espacial e as características da área de ocorrência são informações importantes quando se quer compreender a articulação que define a presença de uma determinada feição. Assim, 
inicialmente, na Tabela 1, têm-se os dados em área das feições erosivas lineares mapeadas no setor.

Tabela 1 - Área ocupada pelas feições erosivas lineares no setor de estudo, por ano.

\begin{tabular}{|c|c|c|}
\hline Feições Erosivas Lineares & Anos & Área de ocorrência em $\left.\mathbf{( m}^{\mathbf{2}}\right)$ \\
\hline \multirow{3}{*}{ Sulcos Erosivos } & 1962 & 828 \\
\cline { 2 - 3 } & 1988 & 1.023 \\
\cline { 2 - 3 } & 2010 & 1.025 \\
\hline \hline \multirow{2}{*}{ Ravinas } & 1962 & 1.955 \\
\cline { 2 - 3 } & 1988 & 1.814 \\
\cline { 2 - 3 } & 2010 & 1.271 \\
\hline \hline \multirow{2}{*}{ Voçorocas } & 1962 & 21.931 \\
\cline { 2 - 3 } & 1988 & 24.486 \\
\cline { 2 - 3 } & 2010 & 36.861 \\
\hline
\end{tabular}

Fonte - Os autores.

Através de uma análise comparativa, identifica-se uma expansão na área de ocorrência de algumas feições lineares do tipo sulco e voçoroca. No que corresponde aos sulcos destaca-se o período de 1962 a 1988, no qual ocorre um aumento de $195 \mathrm{~m}^{2}$ na área de ocorrência; em relação às voçorocas, destaca-se o período de 1988 a 2010, no qual se registra $12.375 \mathrm{~m}^{2}$ de aumento em área. Já nas feições do tipo ravina, identifica-se uma regressão de área de 684 $\mathrm{m}^{2}$ no período total da análise.

A regressão identificada na área ocupada por ravinas entre 1988 e 2010 é acompanhada de um aumento expressivo na área das voçorocas, fato que chama a atenção para o setor leste da bacia hidrográfica, no qual a voçoroca mapeada apresenta expansão abrupta durante o referido período (Tabela 2). Assim, identificou-se através do mapa de feições lineares, que as frentes de expansão do talude erosivo da voçoroca ocorreram sobre feições mapeadas como ravinas em 1988, fato que justifica a diminuição da área identificada entre 1988 e 2010.

Tabela 2 - Expansão da área de ocorrência da voçoroca posicionada no setor leste da área de estudo.

\begin{tabular}{|c|c|}
\hline Ano de análise & Área de ocorrência $\left.\mathbf{( m}^{\mathbf{2}}\right)$ \\
\hline 1962 & 7.699 \\
\hline 1988 & 6.473 \\
\hline $2010 \quad$ Fonte - Os autores. \\
\hline \multicolumn{2}{|c}{} \\
\hline
\end{tabular}

Ainda, identifica-se na área ocupada pela voçoroca apresentada na Tabela 2, uma diminuição em sua dimensão entre 1962 e 1988. O setor de mudança localiza-se próximo a uma estrada rural (Figura 4), fator que alude para a implementação de medidas de contenção erosiva no período, visando preservar a via de acesso. Tal hipótese fundamenta-se na análise das fotografias aéreas utilizadas para os mapeamentos das feições erosivas. Assim, através de tais documentos se constatou uma amenização na rugosidade deste setor durante a transição de 1962 para 1988, possibilitando identificar na área apenas a ocorrência de sulcos erosivos em 1988.

Com relação aos elementos que interferem no desenvolvimento de processos erosivos, as características dos solos e das litologias são fatores importantes. Na área dessa pesquisa os únicos dados disponíveis na bibliografia sobre tais características são de escala de menor detalhe. Contudo, apesar dessa fragilidade, a análise a seguir demonstra que certos aspectos dessas variáveis são definidores da presença das feições erosivas lineares. 
Figura 4 - Destacadas pelas setas, áreas de possíveis aplicações de técnicas de contenção da voçoroca.

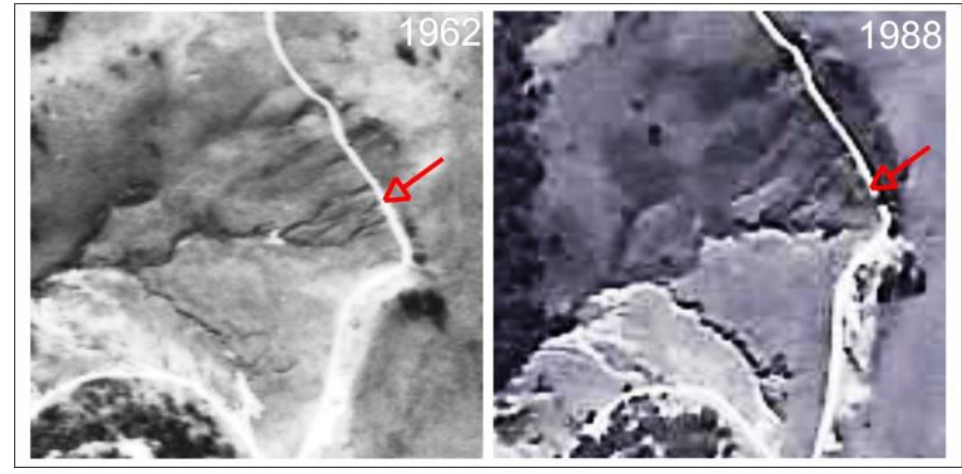

Fonte - Terrafoto, 1962; BASE; 1988.

Do ponto de vista pedológico, a área de estudo possui uma variação expressiva, uma vez que são identificados, a partir do mapeamento de Koffler et al. (1992), cinco tipos de solos, sendo duas classes individualizadas (Argissolos Vermelho-Amarelo Distróficos da Unidade Santa Clara; e Latossolos Vermelho-Amarelo Álico da Unidade Coqueiro) e três em associação (Argissolos Vermelhos Distróficos da Unidade Barão Geraldo e Nitossolos Eutrófico ou Distróficos da Unidade Estruturada; Neossolos Litólicos Eutrófico e Nitossolos Eutrófico ou Distróficos da Unidade Estruturada; e Latossolos Vermelho Amarelo Álico da Unidade Itororó e Plintossolos Pétricos Concecionários).

Através de uma análise comparativa, identificou-se que os setores que mais apresentaram desenvolvimento de sulcos erosivos foram os correspondentes aos solos associados Neossolos Litólicos Eutrófico e Nitossolos Eutrófico ou Distróficos da Unidade Estruturada (Figura 5). No cenário de 1962, 54,2\% da área atingida por sulcos erosivos foram mapeadas nos referidos setores, ocorrendo em 1988 um aumento para $61 \%$ e em 2010 uma diminuição para $45 \%$. Outro tipo de solo que também apresentou porcentagem expressiva de sulcos erosivos foi o Latossolos Vermelho-Amarelo Álico da Unidade Coqueiro, registrando em 1962, 24\% de área de ocorrência; em 1988, 21\%; e em 2010, 25\%.

Ainda analisando a Figura 5, averigua-se que as áreas tomadas por ravinamentos também apresentaram alta concentração nos setores de associação entre os Neossolos Litólicos Eutrófico e Nitossolos Eutrófico ou Distróficos da Unidade Estruturada, sendo mapeadas em $1962,89,5 \%$ das áreas de ocorrência sobre os referidos setores; em 1988, 72,2\% e em 2010 , $84,6 \%$. Identifica-se também, que as feições lineares classificadas como voçorocas apresentaram nos três cenários $100 \%$ da área de ocorrência locada sobre a associação pedológica mencionada. Convém esclarecer que essa associação é apresentada no mapeamento de Koffler et al. (1992) em virtude da escala de trabalho do autor (1:50.000), a qual impossibilita individualizar os solos rasos, típicos do front cuestiforme, daqueles mais profundos derivados da Formação Serra Geral. Assim, quando se aponta tal associação, é importante compreender que os Nitossolos vinculam-se mais diretamente a ocorrência dos processos erosivos, uma vez que na área de estudo as feições de maiores dimensões (ravinas e voçorocas) alcançam sua morfologia característica em solos mais espessos.

Já no que se refere à litologia local, o setor também apresenta grande variação como já mencionado. Comparando e analisando a ocorrência das feições erosivas em relação à litologia, pôde-se identificar uma frequência significativa de sulcos erosivos sobre a Formação Santa Rita do Passa Quatro, uma vez que em 1962, 28,9\% dos sulcos foram identificados nesta, aumentando para 42\% em 1988 e diminuindo para 37\% em 2010 (Figura 6). 
Figura 5 - Ocorrência de feições erosivas lineares em relação aos solos da área de estudo.

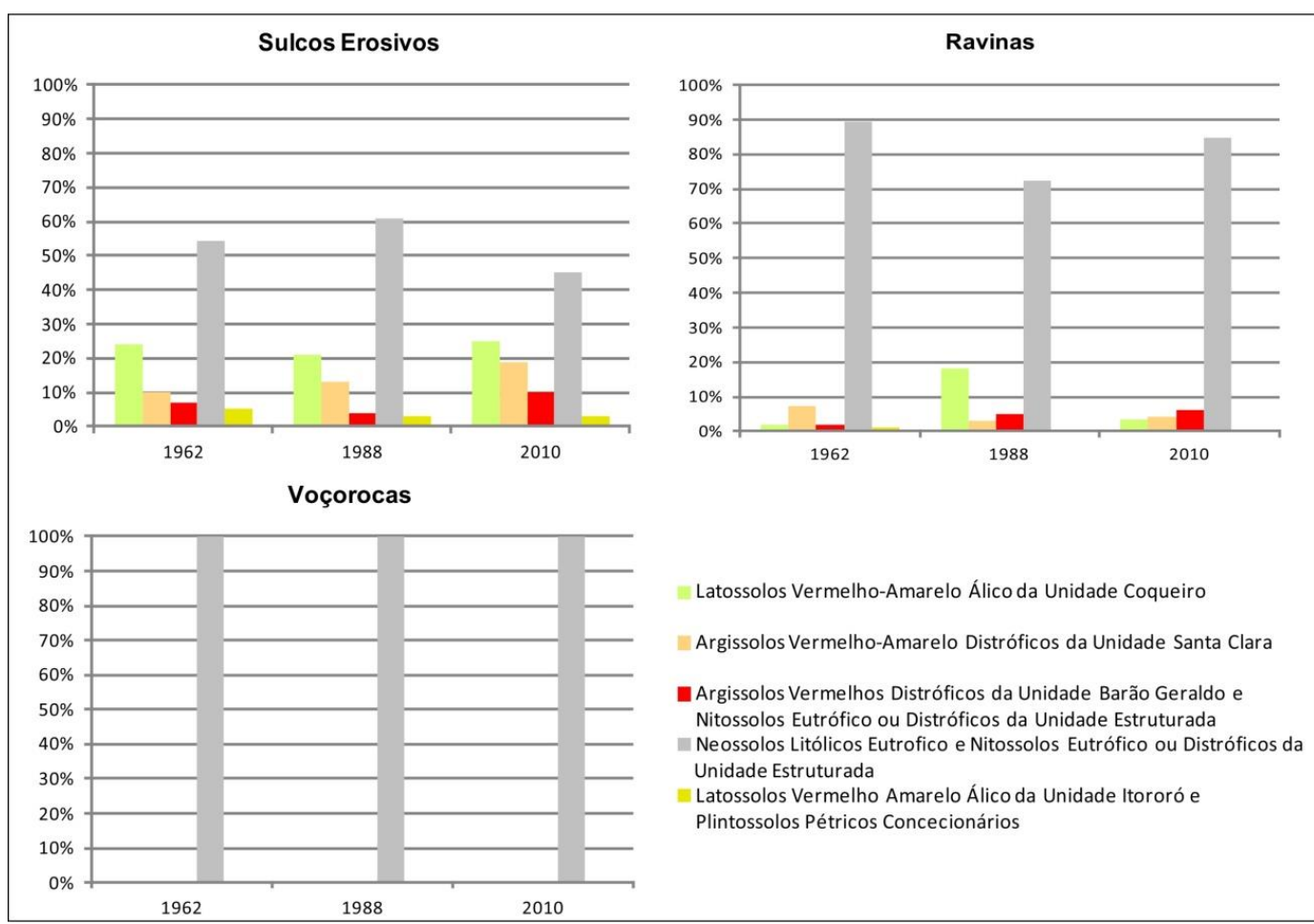

Fonte - Os autores.

Figura 6 - Ocorrência de feições erosivas lineares em relação à litologia da área de estudo.

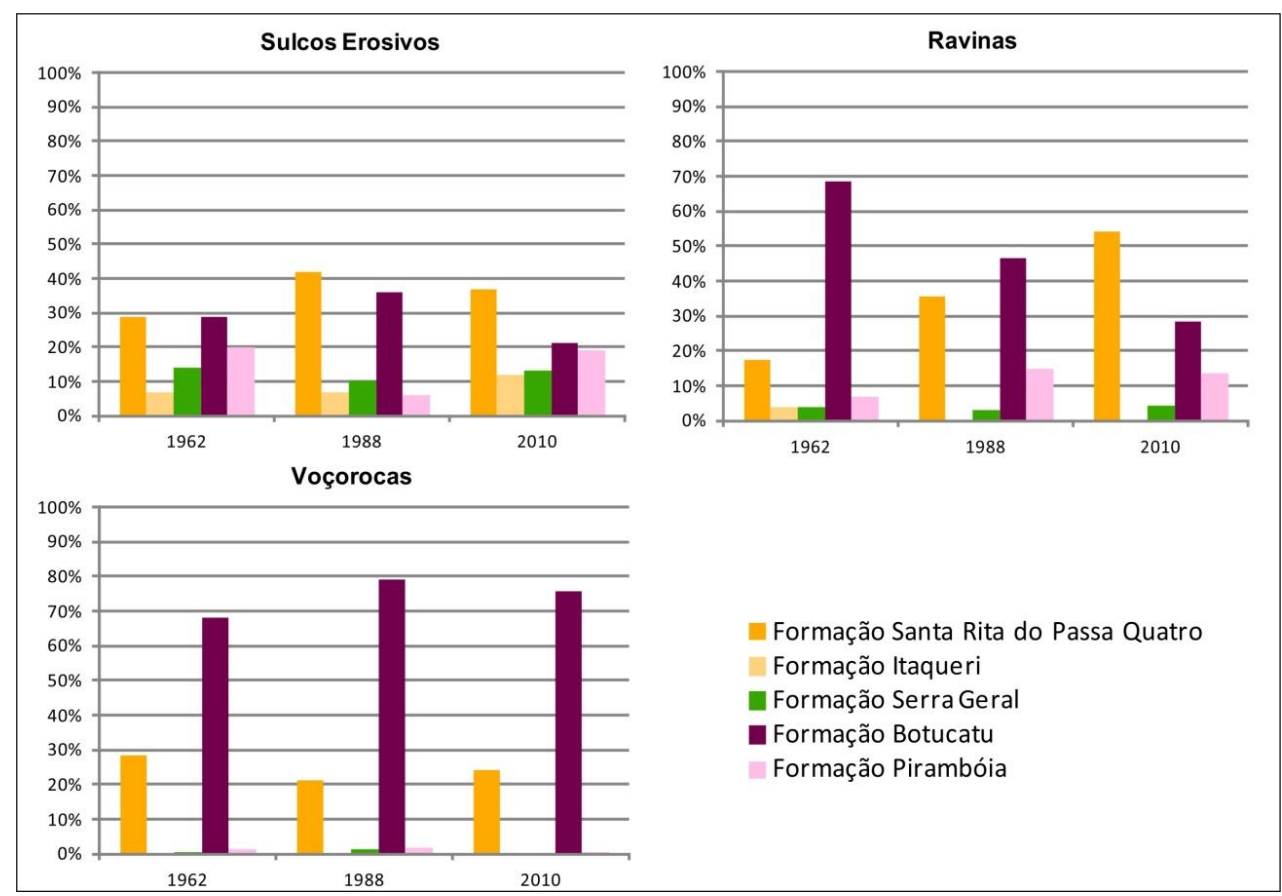

Fonte - Os autores.

Ainda, foi possível constatar que as ravinas apresentam uma concentração sobre a Formação Botucatu no mapeamento datado de 1962, uma vez que 68,4\% possuíam sua área de ocorrência sobre a referida litologia. No entanto, nos anos subsequentes, a ocorrência de ravinamentos fica equilibrada entre as Formações Botucatu e Santa Rita do Passa Quatro, 
apresentando em 1988, 46,6\% de ocorrência sobre a primeira e 35,5\% sobre a segunda; e em $2010,28 \%$ e $54 \%$ respectivamente.

Por fim, constata-se que as ocorrências de voçorocas apresentam-se associadas principalmente a Formação Botucatu, possuindo $68,2 \%$ de área sobre a referida formação geológica em 1962; 79,2\%, em 1988; e 75,7\% em 2010. Tal compreensão ganha relevância regional quando se identifica também a ocorrência de voçorocas em áreas dominadas pelas litologias do Grupo São Bento (Formações Botucatu e Pirambóia) no município São Pedro (SP), fato apontado por Mathias (2016).

Assim, foi possível constatar uma associação das feições erosivas lineares tanto com certos tipos de solos, como com determinadas litologias. É possível realizar tal inferência uma vez que, durante os três anos de análise, os sulcos erosivos apresentaram concentração nos setores de ocorrência de Neossolos Litólicos Eutrófico e Nitossolos Eutrófico ou Distróficos da Unidade Estruturada e sobre a Formação Santa Rita do Passa Quatro. Já nas feições do tipo ravina, foi possível identificar uma associação constante ao longo dos anos com os Neossolos Litólicos Eutrófico e Nitossolos Eutrófico ou Distróficos da Unidade Estruturada; no entanto, no quesito geológico a concentração em uma classe não foi registrada, uma vez que no cenário de 1962 e 1988 a maior ocorrência se dava sobre a Formação Botucatu, sendo a mesma registrada no último ano sobre a Formação Santa Rita do Passa Quatro. Por fim, nas feições classificadas como voçorocas a manutenção dos dados de ocorrência foi marcante, uma vez que, em relação aos solos, registrou-se $100 \%$ de ocorrência sobre os Neossolos Litólicos Eutrófico e Nitossolos Eutrófico ou Distróficos da Unidade Estruturada. Já, no que concerne à litologia, a concentração ocorreu sobre a Formação Botucatu.

Constatou-se também que as feições do tipo sulco apresentaram-se bem distribuídas entre as variáveis naturais trabalhadas, diferentemente das feições erosivas de maior magnitude (ravina e voçoroca), as quais ocorrem dominantemente em algumas classes específicas. Tal dado corrobora com as ideias debatidas por Stefanuto e Lupinacci (2017a), na qual os autores atribuem a variação na ocorrência de sulcos erosivos à influência antrópica através do uso e ocupação da terra, e por Pinton e Cunha (2015), os quais atribuem a variação na ocorrência de sulcos a processo agrícolas responsáveis por obliterações.

Mediante o apresentado, pode-se afirmar ainda que os setores representados pela associação de Neossolos Litólicos Eutrófico e Nitossolos Eutrófico ou Distróficos da Unidade Estruturada e as formações geológicas Botucatu e Santa Rita do Passa Quatro, apresentam suscetibilidade ao desenvolvimento de feições erosivas lineares.

Os Neossolos Litólicos possuem baixo grau de intemperização e consequentemente são poucos evoluídos. São identificados por Oliveira e Prado (1984), na quadrícula São Carlos, que correspondem em parte a área de estudo, com baixo teor de argila (3\% a $7 \%)$ e composição granulométrica predominante de areia fina $(57 \%$ a $61 \%)$ e areia grossa $(34 \%$ a $37 \%)$, fator que alude, como destacado por Alho et al. (2007), para uma baixa unidade dos agregados e consequente suscetibilidade a processos erosivos. Ainda de acordo com Oliveira e Prado (1984), os Neossolos Litólicos da quadrícula apresentam-se associados ao substrato Botucatu/Pirambóia, sendo tais formações geológicas constituídas basicamente por arenitos finos que representam ciclos de sedimentação e alternâncias climáticas de condições quentes e úmidas para desérticas, elemento que contribui para a composição granulométrica do material de superfície (ALMEIDA e BARBOSA, 1953, apud FACINCANI, 2000). Destaca-se que Formação Botucatu, de acordo com Milani et al. (2007), possui seu contato superior de forma concordante e interdigitada com os derrames basálticos da Formação Serra Geral, a qual pode apresentar em sua composição arenitos intertrápicos, elemento este identificado na área de estudo e que permite compreender uma possível associação entre feições erosivas localizadas tanto sobre a Formação Botucatu, como sobre os Nitossolos. Ainda, IAC (2016) e Periçato et al. (2015), descrevem a necessidade de manejo adequado dos Nitossolos, pois, se localizados em áreas declivosas, durantes meses chuvosos e sob determinadas culturas (culturas anuais e cana-de-açúcar) podem apresentar maior suscetibilidade ao desenvolvimento de processos erosivos. Já a Formação Santa Rita do Passa Quatro é composta de 77\% a 94\% de areia finas provenientes de quartzo (MASSOLI, 1981), fator que, para Silva et al. (2005), permite alta erodibilidade aos solos associados a este substrato. Na área de ocorrência desta formação 
identificam-se os Latossolos Vermelho-Amarelo Álicos da Unidade Coqueiro, que são caracterizados por Oliveira e Prado (1984), com granulometria de $66 \%$ a $70 \%$ de areia fina, de $16 \%$ a $20 \%$ de areia grossa e de $10 \%$ a $17 \%$ de argila. Assim, destaca-se que o referido solo engloba em média $23,3 \%$ das ocorrências de sulcos erosivos na área de estudo durante os anos analisados, fator que corrobora com o que aponta o IAC (2014), que os classifica como suscetíveis à degradação sob manejo agrícola.

No que concerne a morfometria, Stefanuto e Lupinacci (2016) classificam o relevo da região com desnível altimétrico abrupto, sendo que os topos chegam a $1040 \mathrm{~m}$, em setores localizados no reverso da cuesta, e a 640 metros, nos fundos de vale locados na depressão periférica, além de apresentarem valores de desnível altimétrico relativo na ordem de $138 \mathrm{~m}$, identificado a partir de mapeamento da profundidade de drenagem. Assim, compreende-se a declividade do relevo como um elemento de suma importância para o entendimento da evolução das feições erosivas, uma vez que pode agregar energia gravitacional às águas das chuvas, possibilitando um aumento na energia de escoamento superficial e de fluxos direcionados.

Assim, a área de estudo apresenta relevo movimentado, sendo $13,1 \%$ do setor caracterizado por declividade de $30-45 \% ; 49,2 \%$ por terrenos com declividade de $12-30 \%$; e $25 \%$ por terreno com declividade de $5-12 \%$. Diante desse cenário, constatou-se que a ocorrência de feições erosivas lineares ocorre majoritariamente nos setores com declividade entre 12 e 30\%, como pode ser analisado na Figura 7.

Figura 7 - Ocorrência de feições erosivas lineares em relação à declividade da área de estudo.

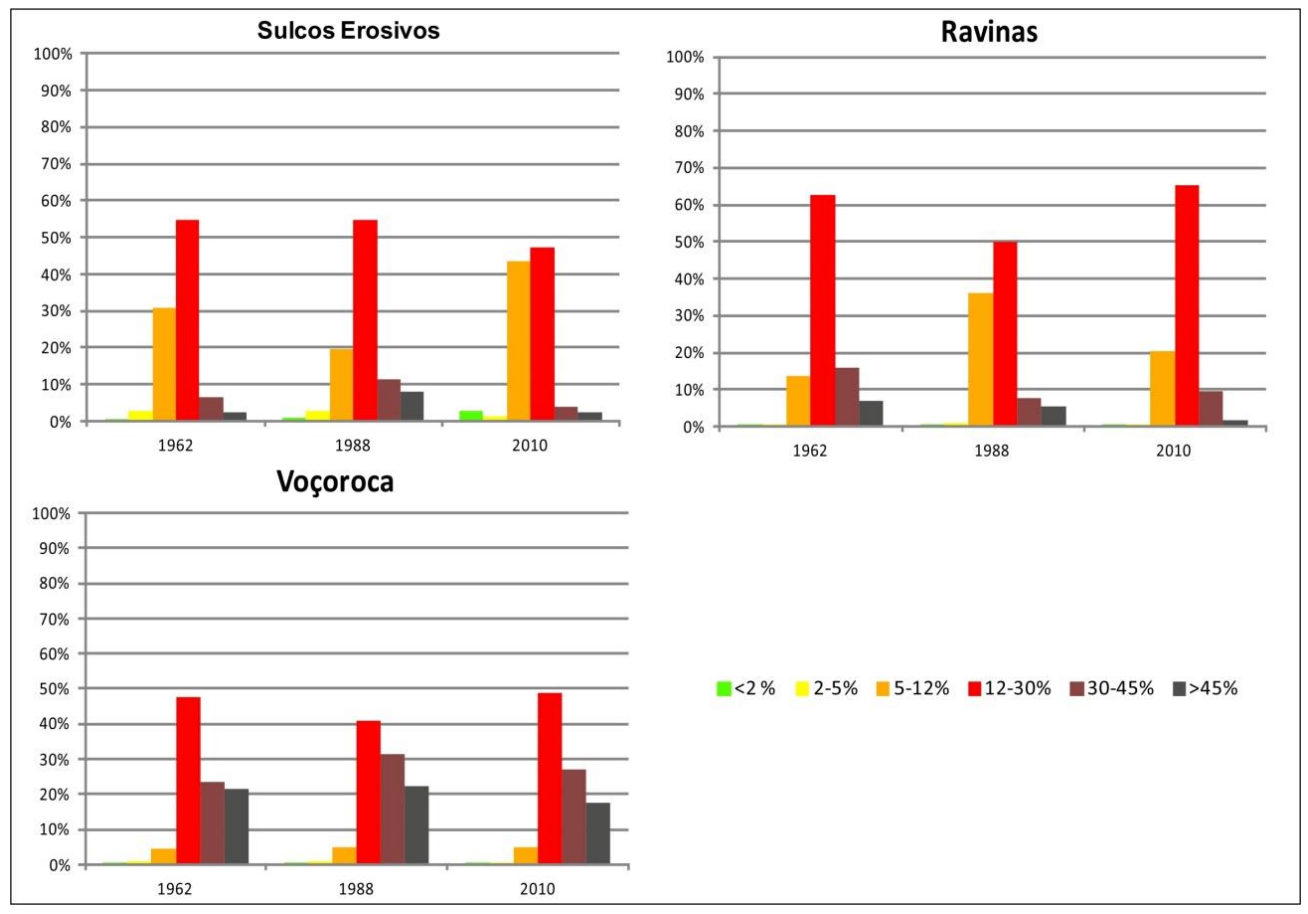

Fonte - Os autores.

No que corresponde aos sulcos erosivos, à ocorrência se dará principalmente nas classes de declividade de $5-12 \%$ e de $12-30 \%$ nos três anos analisados. No entanto, identifica-se uma alta variação ao longo dos anos na área ocupada por tal feição em terrenos com declive de $5-12 \%$, uma vez que em 1962 a ocorrência foi de 30,9\%; em 1988 de 19,6\%; e em 2010 de 43,4\%. A amplitude nos dados pode ser atribuída novamente ao fato de tais feições serem facilmente obliteradas por técnicas de manejo do solo; assim, nos intervalos entre os anos de análise, mudanças no uso ou manejo podem alterar a frequência de ocorrência dos sulcos em uma determinada classe.

Variação similar a dos sulcos é identificada nas áreas de ravinamento, se diferenciando apenas na amplitude e ocorrência de alternâncias nas classes. Assim, em 1962, 13,5\% das ravinas 
foram mapeadas em áreas com declive de $5-12 \%, 62,5 \%$ em declives de $12-30 \%$, e $16 \%$ em declives de $30-45 \%$; em 1988, 36,1\% foram mapeadas em áreas com declive de $5-12 \%, 50 \%$ em declives de $12-30 \%$, e 7,8\% em declives de 30-45\%; e em 2010, 20,4\% em áreas com declive de $5-12 \%, 65,4 \%$ em declives de $12-30 \%$, e $9,6 \%$ em declives de $30-45 \%$. Com isso, identifica-se uma predominância na ocorrência de ravinas na classe de $12-30 \%$ e uma não linearidade na área ocupada por essa feição na classe de $5-12 \%$, a qual é utilizada para fins agrícolas e pode evidenciar mudanças no uso da terra e/ou aplicação de técnicas de manejo do solo que permitem a recuperação ou degradação de setores.

Já nas áreas de voçorocamento, identifica-se uma maior linearidade nos dados, havendo pequenas variações nas classes de 5-12\% (1962, 4,5\%; 1988, 5\%; e 2010, 5,1\%), de $12-30 \%$ (1962, 47,7\%; 1988, 40,8\%; e 2010, 48,6\%), e de 30-45\% (1962, 23,6\%; 1988, 31,6\%; e 2010, $27 \%$ ). A menor oscilação pode ser associada à dificuldade de recuperação de uma área de voçorocamento, ocasionada pela dimensão das feições e a dinâmica evolutiva intensa, elemento que alude à importância de compreensão do declive do terreno em relação às feições erosivas. Além disso, segundo estudo de Stefanuto e Lupinacci (2017a), tais feições também estão associadas a setores com média e alta densidade de lineamentos, demonstrando uma possível interferência morfoestrutural. No que se refere ao uso e ocupação da terra em 2010, identifica-se uma predominância de pastagens no setor, com destaque para os pastos limpos que ocupam $51 \%$ da área. Outro uso que ganha relevância é a vegetação arbórea que recobre $29,7 \%$ da bacia hidrográfica. Destacam-se ainda as classes de pasto degradado (1,7\%), pasto sujo $(3,12 \%)$, solo exposto $(1,1 \%)$ e vegetação invasora $(2,34 \%)$, as quais são responsáveis por caracterizarem áreas com baixo uso de técnicas conservacionistas, fato atestado em campo em diversos setores da área de estudo.

No que se refere ao uso e ocupação da terra e a ocorrência de feições erosivas lineares no ano de 2010, é possível estabelecer uma estreita relação entre algumas feições e classes usos, conforme é apresentado na Figura 8.

Figura 8 - Ocorrência de feições erosivas lineares em relação ao uso e ocupação da terra em 2010.

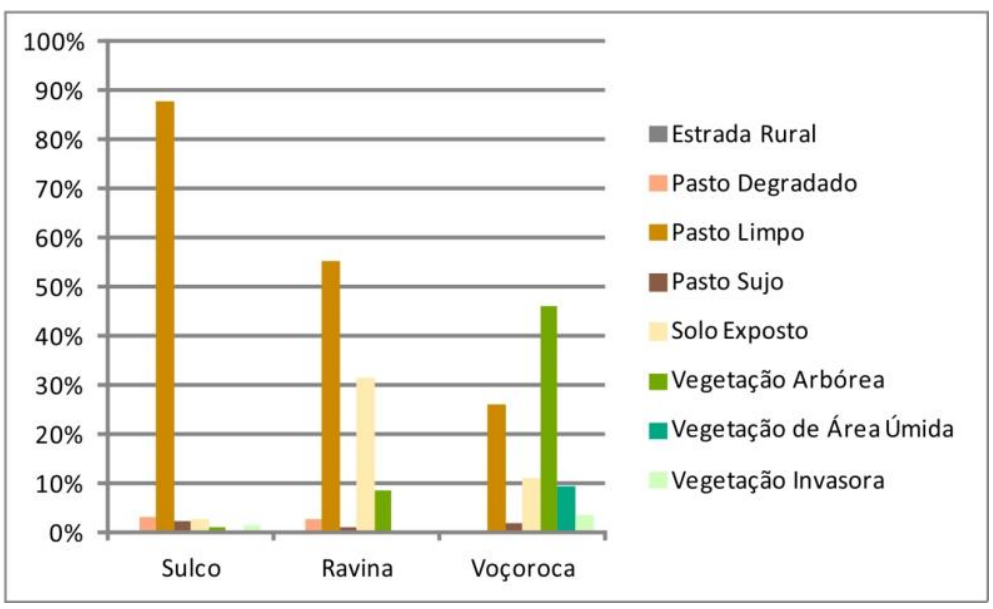

Fonte - Os autores

Constata-se uma relação marcante entre a ocorrência de feições erosivas do tipo sulco e as áreas mapeadas como pasto limpo. Tal correlação se deve também ao critério de análise, sendo os sulcos caracterizados como pequenos canais que direcionam o fluxo de água do escoamento superficial, feição comum em áreas com fins para pecuária.

No que corresponde às ravinas, a ocorrência fica concentrada principalmente em dois usos, sendo esses: pasto limpo $(55,3 \%)$ e solo exposto $(31,5 \%)$. A maior ocorrência de ravinas em áreas de pastagem possui relação estreita com o desenvolvimento e aprofundamento de sulcos erosivos em função de caminhos preferências utilizadas pelos bovinos. Com a evolução rápida dos sulcos para ravinas e o próprio desenvolvimento das ravinas, a vegetação não se instala com tanta facilidade no setor, assim grande parte das ravinas apresentaram seu interior sem vegetação, sendo essas áreas classificadas no mapa de uso da terra como solo exposto. 
Já as áreas de voçorocamento são ocupadas majoritariamente pelas classes de vegetação arbórea (45,9\%) e pasto limpo (25,9\%). Os dados evidenciam ainda a maior expressividade das classes vegetação invasora (3,9\%) e vegetação de área úmida $(9,4 \%)$. No que corresponde aos índices de vegetação arbórea e invasora, foi constatado em campo que as mesmas se desenvolvem em grande parte no interior das voçorocas, áreas as quais se apresentam inviáveis para o uso agrícola e limitadas para pecuária, fazendo com que os proprietários abandonem os setores e as espécies arbustivas e arbóreas se instalem. Já o aumento da área ocupada pela vegetação de área úmida, ocorre em função do desenvolvimento das voçorocas e possíveis contatos com o lençol freático, causando 0 afloramento de água e a instalação de vegetação hidrófila.

No que se refere às espécies exóticas, Valentin et al. (2005) também constataram que as voçorocas constituem-se em um reduto para o desenvolvimento de espécies vegetais não nativas, sendo que estas tendem a ocupar as áreas de entorno da feição. Assim, identifica-se nesta pesquisa que a espécie Tecoma stans passa a ocupar o talude e área de entorno de uma voçoroca localizada a oeste da bacia hidrográfica, fazendo com que espécies perenifólias, típicas da vegetação local, não venham a se desenvolver.

A inibição do desenvolvimento de espécies perenifólias na área do talude constitui-se uma problemática, uma vez que se averigua em campo que a evolução do talude da voçoroca pode ser facilitada pela vegetação invasora, a qual apresenta caráter caducifólio durante o período de inverno. Tal especificidade permite suscetibilidade à atuação de processos erosivos, o qual contribui com o carreamento de material através do escoamento laminar. Ainda, buscando evidenciar a diferença fitofisionômica, apresenta-se uma imagem comparativa entre a vegetação invasora em período seco e em período úmido (Figura 9). Assim, no início do período úmido, a cobertura vegetal está comprometida, podendo colaborar para a dinamização das ações erosivas.

Figura 9 - Espécie Tecoma stans em período seco (agosto de 2017) e período úmido (janeiro de 2018).

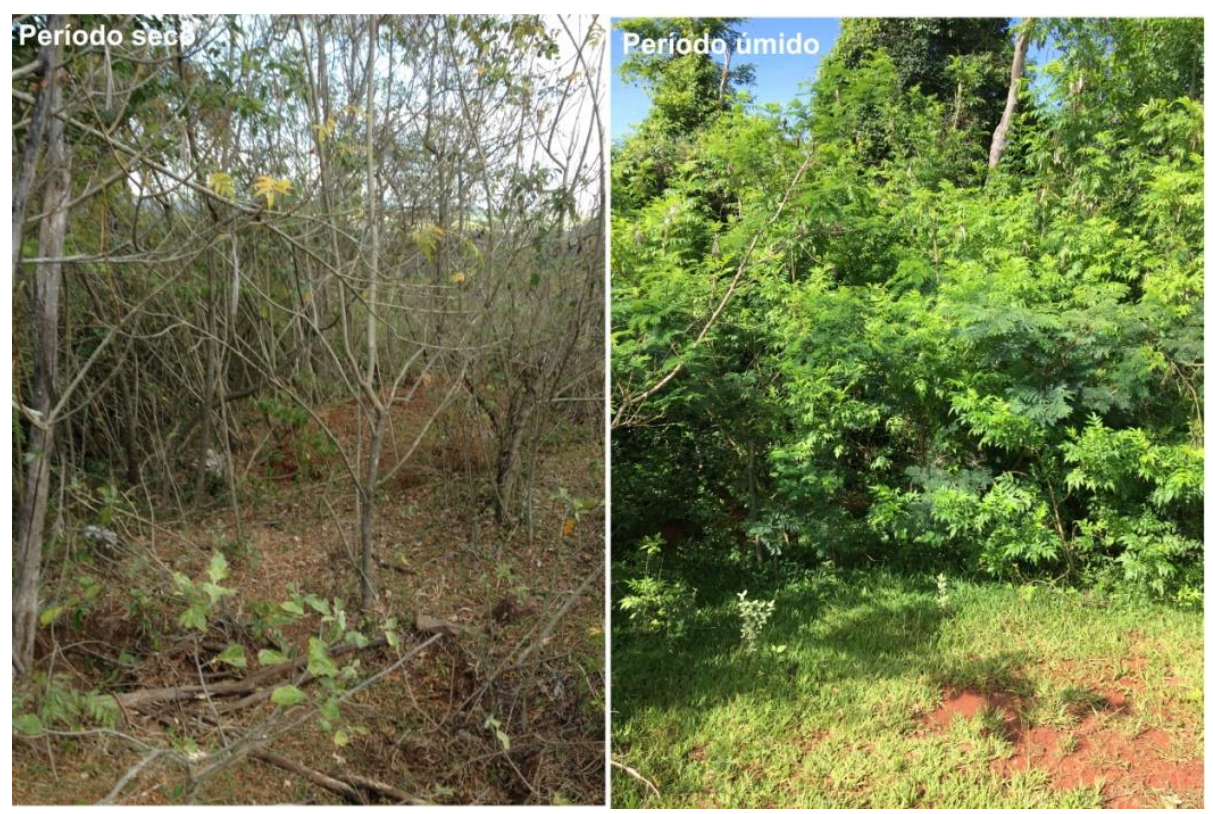

Fonte - Acervo pessoal dos autores.

\section{CONSIDERAÇÕES FINAIS}

O presente artigo apresenta um levantamento dos elementos do terreno que influenciam a dinâmica evolutiva das feições erosivas lineares, destacando quais especificidades de cada elemento contribuem de forma mais significativa em sua ocorrência e evolução. No que corresponde aos solos, parte dos Nitossolos da área podem apresentar, de acordo com a bibliografia, suscetibilidade ao desenvolvimento de processos erosivos, uma vez que estão 
localizados em áreas declivosas. Os Neossolos Litólicos Eutróficos apresentam uma baixa unidade dos agregados e consequente suscetibilidade ao desenvolvimento de processos erosivos, fato comprovado por apresentarem, juntamente com os Nitossolos, a maior área de ocorrência de feições erosivas lineares do setor estudado. Destacam-se ainda os Latossolos Vermelho-Amarelo Álicos da Unidade Coqueiro, que possuem sua granulometria composta de $66 \%$ a $70 \%$ de areia fina, fator que colabora para uma ocorrência significativa $(23,3 \%)$ de sulcos durante o período de análise.

Em relação à litologia, identificou-se uma concentração de sulcos sobre a Formação Santa Rita do Passa Quatro; uma alternância na ocorrência de ravinas entre as Formações Botucatu e Santa Rita do Passa Quatro; e uma predominância na ocorrência de voçorocas sobre a Formação Botucatu. Destacou-se também uma possível ocorrência de feições erosivas em áreas de contato entre as Formações Botucatu e Serra Geral, as quais se apresentam, de acordo com Milani et al. (2007), de forma concordante e interdigitada, havendo assim, uma relação na ocorrência de feições erosivas tanto em áreas da Formação Botucatu, como em áreas de Nitossolos. Ainda, constatou-se uma associação das voçorocas a setores com média e alta densidade de lineamentos (STEFANUTO E LUPINACCI, 2017a).

No que se refere à declividade do terreno, elemento de suma importância para compreensão do desenvolvimento de feições erosivas, analisou-se que nos três anos selecionados, a ocorrência de sulcos erosivos e ravinas se deram principalmente nas classes de declividade de $5-12 \%$ e de $12-30 \%$; já as ravinas distribuíram-se nas classes de declividade de $5-12 \%, 12$ $30 \%$ e $30-45 \%$. Assim, foi possível verificar uma associação das feições erosivas de menor destaque na paisagem (sulcos e ravinas) a declives, classificados pelo IBGE (2009), como fortes, mas também em declives moderados, passíveis até de mecanização agrícola no caso da classe de 5 a 12\%. Já as voçorocas também se associaram aos declives moderados e fortes, possuindo ainda parte de sua ocorrência em declives classificados como muito fortes.

Em relação ao uso e ocupação da terra averiguou-se uma relação marcante entre a ocorrência de feições erosivas do tipo sulco e as áreas mapeadas como pasto limpo; às ravinas em relação ao pasto limpo (55,3\%) e ao solo exposto (31,5\%); e as voçorocas ocupadas majoritariamente pela vegetação arbórea (45,9\%) e pasto limpo (25,9\%). Assim, identificou-se uma suscetibilidade de setores mapeados como pasto limpo ao desenvolvimento de feições erosivas como os sulcos e as ravinas, no entanto o referido uso não apresenta relevância semelhante nas áreas de voçorocamento, uma vez que os setores tendem a ser abandonados pelos proprietários, ocorrendo à instalação de espécies vegetais no interior da voçoroca as quais muitas vezes são invasoras, com índice de massa foliar baixo em função de seu caráter caducifólio.

Assim, os dados apresentados nesse trabalho ilustram as características geológicasgeomorfológicas do contato depressão-cuesta, marcadas por diversificadas litologias, que dão origem a variações pedológicas significativas que se correlacionam também a diversos graus de declive. Nesse cenário, constata-se que a presença de feições erosivas lineares responde tanto a certas características físicas que denotam fragilidade erosiva, como a certas condições de uso da terra, as quais podem propiciar o desenvolvimento de tais feições sobre condições físicas pouco prováveis.

\section{AGRADECIMENTOS}

À Fundação de Amparo à Pesquisa do Estado de São Paulo - FAPESP, pelo financiamento. Processo no 2016/25399-1.

\section{REFERÊNCIAS}

ALHO, D. R.; MARQUES JÚNIOR, J.; CAMPOS, M. C. C. Caracterização física, química e mineralógica de Neossolos Litólicos de diferentes materiais de origem. Revista Brasileira de Ciências Agrárias. v.2 n.2 p.117-122, 2007. https://doi.org/10.5039/agraria.v2i2a183

ALMEIDA, F. F. M. de. Relevo de "Cuestas" na Bacia Sedimentar do Rio Paraná. Boletim Paulista de Geografia. n. 3, p. 21-33, 1949. 
ALMEIDA, F. F. M. de. Fundamentos Geológicos do Relevo Paulista. São Paulo: IGEOG, 1974.

AUGUSTIN, C. H. R. R.; ARANHA, P. R. A. A ocorrência de voçorocas em Gouveia, MG: Características e Processos Associados. Geonomos. n.14, p.75-86, 2006.

BASE - BASE Aerofotogrametria e Projetos S/A. Levantamento aéreo do Estado de São Paulo de 1988. São Paulo, 1988. No color. Escala 1:40000.

BRASIL. Lei no 6.766, de 19 de dezembro de 1979. Disponível em: < http://www.planalto.gov.br/ccivil_03/leis/l6766.htm>. Acesso em: 11 de julho de 2018.

BRASIL. Lei no 12.651, de 25 de maio de 2012. Disponível em: < http://www.planalto.gov.br/ccivil_03/_Ato2011-2014/2012/Lei/L12651.htm\#art83>. Acesso em: 10 de abril de 2018.

CAMPOS, S.; CAMPOS, M. de.; GOBB, T. T. A. Espacialização do Conflito de Uso da Terra em Áreas de Preservação Permanentes da Bacia do Rio Capivara - Botucatu/SP. In: CAMPOS, S.; PISSARRA, T. C. T.; CAMPOS, M (Org.). Geotecnologia Aplicada no Planejamento Ambiental de Bacias Hidrográficas. Tupã: ANAP, 2015. p. 91-114.

CASSETI, V. Elementos de Geomorfologia. Goiânia: Editora UFG, 2001.

CERON, A. O.; DINIZ, J. A. F. O uso das fotografias aéreas na identificação das formas de utilização agrícola da terra. Revista Brasileira de Geografia. n. 2, v. 28, p. 161-173, 1966.

CHRISTOFOLETTI, A.; QUEIROZ NETO J. P. Estudos Geomorfológicos a respeito da Serra de Santana, SP. Boletim Paulista de Geografia. n. 38, p. 3-20, jun/1961.

DE BIASI, M. A carta clinográfica: Os métodos de representação e sua confecção. Revista do Departamento de Geografia (USP). São Paulo, n. 6, p. 45-60, 1992. https://doi.org/10.7154/RDG.1992.0006.0004

DE BIASI, M. Cartas de declividade: confecção e utilização. Geomorfologia. São Paulo, n. 21, p. 8-13, 1970.

DERRUAUX, M. Précis de Géomorphologie. Paris: Masson, 1965.

EMPLASA - Empresa Paulista de Planejamento Metropolitano. Projeto Mapeia São Paulo. São Paulo, 2010. Color. Escala 1:25000.

FACINCANI, E. M. Morfotectônica da depressão periférica paulista e cuesta basáltica: regiões de São Carlos, Rio Claro e Piracicaba, SP. 2000. 222 f. Tese (Doutorado em Geologia Regional) - Instituto de Geociências e Ciências Exatas, Universidade Estadual Paulista, Rio Claro, 2000.

FURLANI, G. M. Estudo geomorfológico das boçorocas de Casa Branca - São Paulo. 1980. 379f. Dissertação. Departamento de Geogafia (FFLCH), São Paulo, 1980.

GOUDIE, A. S. Encyclopedia of Geomorphology (Volume 1). London and New York: Routledge, 2004.

GUERRA, A. T.; GUERRA, A. J. T. Novo Dicionário Geológico-Geomorfológico. 8 eds. Rio de Janeiro: Bertrand Brasil, 2010.

IAC - INSTITUTO AGRONÔMICO DE CAMPINAS. Solos do Estado de São Paulo. 2014. Disponível em: <http://www.iac.sp.gov.br/solossp/> Acesso em: 19 de fevereiro de 2018.

IAC - INSTITUTO AGRONÔMICO DE CAMPINAS. Recomendações Gerais para Conservação do Solo na Cultura da Cana-de-açúcar. Boletim Técnico IAC 216. Campinas, 2016.

IEA - INSTITUTO DE ECONOMIA AGRÍCOLA. Estatísticas da Produção Paulista. 2017. Disponível em: < http://ciagri.iea.sp.gov.br/nia1/subjetiva.aspx?cod_sis=1\&idioma=1> Acesso em: 02 de abril de 2018.

IBGE - INSTITUTO BRASILEIRO DE GEOGRAFIA E ESTATÍSTICA. Manual Técnico de Geomorfologia. Rio de Janeiro, 2009. 
IBGE - INSTITUTO BRASILEIRO DE GEOGRAFIA E ESTATÍSTICA. Manual Técnico de Uso da Terra. Rio de Janeiro, 2013.

IBGE - INSTITUTO BRASILEIRO DE GEOGRAFIA E ESTATÍSTICA. Sistema IBGE de Recuperação Automática (SIDRA): Produção Agrícola Municipal (PAM). Rio de Janeiro, 2016. Disponível em: <https://sidra.ibge.gov.br/pesquisa/pam/tabelas>. Acesso em: 02 de abril de 2018.

IBGE - INSTITUTO BRASILEIRO DE GEOGRAFIA E ESTATÍSTICA. Malhas Territoriais de 2017. Rio de Janeiro, 2017. No color. Escala 1:250000. Disponível em: $<$ https://www.ibge.gov.br/geociencias-novoportal/downloads-geociencias.html>.

IG - INSTITUTO GEOLÓGICO DO ESTADO DE SÃO PAULO. Formações Geológicas de Superfície. 1984.

KOFFLER, N. F.; MACHADO, M. L. de. A.; DAROS, E.; PROCHNOW, E. A. Solos da bacia do Rio Corumbataí. Rio Claro: Departamento de Cartografia e Análise da Informação Geográfica - Instituto de Geociências e Ciências Exatas, Universidade Estadual Paulista, 1992. Escala: 1:50.000

MASSOLI, M. Geologia do Município de Santa Rita do Passa Quatro. Revista do Instituto Geológico. n. 2, p. 35-45, 1981. https://doi.org/10.5935/0100-929X.19810009

MATHIAS, D. T. Contribuição Metodológica para o Diagnóstico da Dinâmica Erosiva Linear e seu Prognóstico Evolutivo visando subsidiar Projetos de Recuperação._2016. 178 f. Tese (Doutorado em Geografia). Faculdade de Ciências e Tecnologias, Universidade Estadual Paulista - UNESP, Presidente Prudente, 2016.

MILANI, E. J.; MELO, J. H. G. de; SOUZA, P. A. de; FERNANDES, L. A.; FRANÇA, A. B. Bacia do Paraná. Boletim de Geociências da Petrobras. v.15, n.2, p. 265-287, 2007.

OLIVEIRA, J. B. de; PRADO, H. do. Levantamento Pedológico Semidetalhado do Estado de São Paulo: Quadrícula de São Carlos - II Memorial Descritivo. Boletim Técnico № 98. Campinas: Instituto Agronômico, 1984.

PEDROSA-MACEDO, J. H.; BREDOW, E. A. Princípios e rudimentos do controle biológico de plantas: coletânea. Curitiba: [s.n.], 2004.

PENTEADO, M. M. Fundamentos de Geomorfologia. Rio de Janeiro: IBGE, 1974. 141 p.

PERIÇATO, A. J.; MARCATTO, F. S.; SILVEIRA, H. Comportamento físico-hídrico do Nitossolo Vermelho: subsídios a gestão dos recursos hídricos na bacia hidrográfica do Pirapó-ParanáBrasil. In: SAFETY, HEALTH AND ENVIRONMENT WORLD CONGRESS. 15. 2015, Porto Portugal. Anais... Porto, 2015. p. 306-310.

PINTON, L. de G. A Antropogeomorfologia na bacia do Córrego do Cavalheiro Analândia/SP: Uma avaliação da dinâmica de uso da terra e sua adequabilidade a legislação ambiental e a capacidade de uso. 2011. 102 f. Trabalho de Conclusão de Curso - Instituto de Geociência e Ciências Exatas, Universidade Estadual Paulista, Rio Claro, 2011.

PINTON, L. de G.; CUNHA, C. M. L. O Uso de Geoindicadores em Paisagem Rural: Subsídios à Análise das Mudanças Morfológicas Antropogênicas da Bacia do Córrego Do Cavalheiro Analândia (SP). Revista do Departamento de Geografia - USP. v.29, p. 1-19, 2015. https://doi.org/10.11606/rdg.v29i0.102128

ROOS, J. L. S. Os Fundamentos da Geografia da Natureza. In: ROSS, J. L. S. (Org.) Geografia do Brasil. São Paulo: Editora da Universidade de São Paulo, 2009. p. 13-51.

SILVA, R. F. da.; CANÇADO C. J.; LORANDI, R.; GALIANO, V A., MOREIRA, M. A. A. Aplicação metodológica para seleção de áreas para disposição de resíduos sólidos industriais cerâmicos. Estudo de caso: Porto Ferreira - SP. Geociências. v. 24, n.3, p. 305-317, 2005.

SSSA - SOIL SCIENCE SOCIETY OF AMERICA. Glossary of Soil Scienci Terms. Madison: Soil Scienci Society of America, 2008. 
SOUZA, T. de A. de.; OLIVEIRA, R. C. de. Avaliação da potencialidade de imagens tridimensionais em meio digital para o mapeamento geomorfológico. Revista Geonorte. v. 2, N.4, p.1348-1355, 2012

STEFANUTO, E. B.; LUPINACCI, C. M. Aspectos Morfoestruturais do Relevo em Setor de Cuestas: Um Estudo em Analândia (SP). Revista Brasileira de Geografia Física. v. 9, n. 4, 2016. https://doi.org/10.5935/1984-2295.20160081

STEFANUTO, E. B.; LUPINACCI, C. M. Análise da dinâmica erosiva presente no setor cuestiforme de Analândia (SP). In: ENCONTRO NACIONAL DA ANPEGE. 12. 2017, Porto Alegre. Anais... Porto Alegre, 2017a. p. 11625-11636.

STEFANUTO, E. B.; LUPINACCI, C. M. Atuação dos sistemas de forçamento nos sistemas terrestres a partir da ação antrópica. In: SIMPÓSIO NACIONAL DE GEOGRAFIA FÍSICA APLICADA e CONGRESSO NACIONAL DE GEOGRAFIA. 17 e 1. 2017, Campinas. Anais... Campinas, 2017b. p. 6151-6161. https://doi.org/10.20396/sbgfa.v1i2017.2505

TERRAFOTO - TERRAFOTO S/A Aerolevantamentos. Levantamento aéreo do Estado de São Paulo de 1962. São Paulo, 1962. No color. Escala 1:25000.

TRICART, J. Principes et méthodes de la géomorphologie. Paris: Masson, 1965. https://doi.org/10.1097/00010694-196510000-00015

VALENTIN, C.; POESEN, J.; YONG LI. Gully erosion: Impacts, factors and control. Catena. $n$. 63, p.132-153, 2005. https://doi.org/10.1016/j.catena.2005.06.001

VERSTAPPEN, H. T.; ZUIDAN, R. A. van. ITC System of geomorphological survey. Manual ITC Textbook, Netherlands: Enschede. V. 1, cap. 8, 1975.

Recebido em: 23/07/2018

Aceito para publicação em: 09/11/2018 